\title{
Residential Tourism, Swimming Pools, and Water Demand in the Western Mediterranean
}

\author{
Álvaro-Francisco Morote \\ University of Alicante
}

David Saurí

Autonomous University of Barcelona

\section{María Hernández \\ University of Alicante}

\begin{abstract}
Many Mediterranean areas have recently witnessed a proliferation of new urban and tourist-related features following lowdensity residential patterns that contrast with the traditional high-density urban typologies of Mediterranean cities. The aim of this research is to investigate the links between residential tourism and water consumption through swimming pools, which constitute one key element of the new urban landscapes in the coast of Alicante (southeastern Spain). We have digitized pools in nine municipalities of coastal Alicante and calculated the average depth and estimated water losses due to evaporation. Results show that swimming pools are widely available in tourist residential enclaves but that they tend to display different characteristics according to factors such as the history of the urbanization process and relative wealth of the different areas. We have detected a clear contrast between the large individual pools of the richer northern municipalities and the smaller individual pools and community pools in the newly developed but less well-off urban enclaves of the southern coast. Key Words: consumption, Mediterranean, swimming pools, tourism, water.
\end{abstract}

晚近诸多地中海地区, 随着地中海城市的低密度住宅模式对比传统高密度城市的模型, 见证了新兴城市与观光相关的特徵之 扩散。本研究的目的, 便是透过游泳池, 探讨旅居观光与水资源消费之间的连结, 而游泳池则是构成阿利坎特 (西班牙东南 方) 沿海的新兴城市地景的一项主要元素。我们将阿利坎特沿海九座行政区中的游泳池进行数码化, 并计算平均深度, 以及 估计因蒸发所导致的水资源损失。研究结果显示, 游泳池在观光客居住的飞地中广泛可及, 但它们根据诸如城市化过程的历 史, 以及不同地区的相对财富等因素, 倾向呈现不同的特徵。我们侦测到较富裕的北方行政区的大型个人游泳池, 及其与新 开发但较不富裕的南方沿海城市飞地的小型个人泳池和社区游泳池之间的明显对比。关键词: 消费, 地中海, 游泳池, 观光, 水资源。

Recientemente, muchas áreas mediterráneas han presenciado la proliferación de nuevos rasgos urbanos y aquellos que se relacionan con turistas, siguiendo los patrones residenciales de baja densidad que contrastan con las tipologías tradicionales urbanas de alta densidad de las ciudades mediterráneas. El objeto de este estudio es investigar los vínculos que existen entre el turismo residencial y el consumo de agua para piscinas de natación, que constituyen un elemento clave de los nuevos paisajes urbanos de la costa de Alicante (sudeste de España). Hemos digitalizado las piscinas de nueve municipalidades del Alicante costero y calculado la profundidad promedia y pérdidas estimadas de agua por evaporación. Los resultados muestran que las piscinas de natación proliferan en los enclaves turísticos residenciales pero que aquellas tienden a desplegar diferentes características de acuerdo con factores tales como la historia del proceso de urbanización y la riqueza relativa de las diferentes áreas. Hemos detectado un claro contraste entre las grandes piscinas de natación individuales de las municipalidades ricas del norte y las más pequeñas piscinas individuales y piscinas de natación comunitaria de los recientemente desarrollados, si bien menos afluentes, enclaves urbanos de la costa sudeste. Palabras clave: consumo, Mediterráneo, piscinas de natación, turismo, agua.

$\mathbf{U}$ rbanization, especially under its sprawled form, is rapidly changing many traditional environments and societies (European Environment Agency 2006). In Mediterranean areas, low-density urban growth proliferates in the peripheries of traditional compact cities (Salvati and Sabbi 2011) and also in the peripheries of mass tourism enclaves, in this latter case under the so-called form of residential tourism. McWatters (2009) defined residential tourism "as the enduring practices and lifestyles which result from a channelled flow of consumption-led permanent or semi-permanent migration to a particular destination" (3). This concept has been used in Spain since the late 1970s to explain the social, economic, and land changes generated by the increase in two forms of human mobility: tourism and migration (Vera 1987; Huete, Mantecón, and Mazón 2008; Casado 2012). In the Mediterranean, residential tourists have a long tradition in certain areas such as the French Cote d'Azur (Fernández and Barrado 2011), Tuscany and other 
areas of the Italian coast (Salvati et al. 2015), the Costa del Sol (Raya and Benítez 2002), and Majorca (Salvà 2002). The spread of residential tourism in the Mediterranean is due to a variety of reasons; for example, affordable cost of living for Western and Northern Europeans; frequent and inexpensive flying connections to main European destinations; low taxes; and free or cheap health services, among other amenities. In Mediterranean Spain and in terms of land use patterns, residential tourism usually develops in three main typologies: single housing, condominiums, and apartment blocks (Morote 2014). Of these, apartment blocks tend to be found mostly in the coastal zone, whereas condominiums and single houses can be found both near the coast and in the hilly hinterlands (Hof and Blázquez 2013). In the United States, retirement migration to Florida, Texas, and Arizona would indicate similar processes, although in this case the word tourism is not used (McWatters 2009).

The characteristics that define urban patterns, especially those related to housing typologies, can be decisive in terms of gaining a better understanding of water demand (Rico 2007; Morote and Hernández 2016). Hence, in per capita terms, the consumption of water in high-density urban areas is lower than in low-density urban areas because in the latter there might be an important presence of water-consuming features such as gardens and swimming pools (Vidal, Domene, and Saurí 2011). In semiarid and arid environments, gardens have become a large consumer of water, partly as a consequence of the proliferation of lawns (Fernández, Ordovás, and Herrera 2011; Salvador, Bautista-Capetillo, and Playán 2011; Parés, March, and Saurí 2013) and the introduction of deciduous plants, which generate new urban natures many times with little resemblance to original seminatural ecosystems (Robbins 2012). On the other hand, swimming pools have also contributed in significant ways to outdoor water consumption (Hof and Wolf 2014), not only because pools themselves require considerable amounts of water but also because swimming pools tend to be positively correlated with plot size. In sum, gardens and swimming pools contribute to generate specific urban metabolic processes (Swyngedouw 1999, 2014) in which increasing flows of water are diverted toward nonessential uses. Plot size, the purchasing power of the owners, and climatic features (more or less aridity) explain garden sizes and the proportion between gardens and paved areas. The size of pools is also determined by the income of the owner and the size of the plot (Rico, Olcina, and Saurí 2009; Morote and Hernández 2014).

Installing an outdoor swimming pool constitutes one of the many ingredients in the pursuit of a supposedly better quality of life in the suburban areas of the developed world. Although depending on specific temporal and spatial patterns in different countries, suburbanization generally involves a considerable segment of the population in core neighborhoods leaving the city to settle in the urban periphery. Furthermore, moving in other areas often implied changing housing type as well, so that single houses and condominiums became the normal urban landscape of suburban spaces instead of the apartment blocks of city centers. Besides, the size of the lot, especially in the postWorld War II burgeoning cities of the U.S. West and South, and Australia, allowed for the presence of a private garden (normally a lawn) and a swimming pool. The latter have been especially successful in semiarid areas with warm summers such as the western and southern United States or Mediterranean Europe.

Several studies have found a significant positive relationship between the presence of swimming pools and water consumption in the residential sector (Domene and Saurí 2006; Wentz and Gober 2007; Balling, Gober, and Jones 2008). If climate change and water scarcity scenarios in the Mediterranean become true, the meeting of the water needs of tourists and local residents could become a challenge and outdoor uses that are critical for tourism could be threatened (Gössling et al. 2012). The impacts of sprawl are well documented, with energy and land consumption often targeted as the main environmental problems (Couch, Petschel-held, and Leontidou 2007; Catalán, Saurí, and Serra 2008; Salvati and Sabbi 2011). In certain climates, however, water also enters the equation and becomes an item of the utmost importance for planners and managers because water-dependent elements in the form of lawns, gardens, swimming pools, and so on, begin to dot profusely urban landscapes (Askew and McGuirk 2004; Gössling 2015). It is therefore important to characterize the new uses of water that emerge from the expanding residential areas and even more so when water might be scarce or in high demand by other uses such as irrigated agriculture. Both constraints are fairly common in the Mediterranean, especially in summer (Staddon 2010; Cole 2014).

Swimming pools are one of the more common (and less studied) components of urban landscapes associated with residential tourism. Their use is associated with leisure activities in Western societies (Van Leeuwen 1999; Wiltse 2007; Wolf and Hof 2013), and pools have become a common element in the sprawling areas of many cities (Salvati et al. 2015). Pools in the richer world, especially, constitute part of the myriad of artefacts associated with suburban environments and the landscapes of "high-carbon lives" of residential and tourist settings (Leichenko and Solecki 2005; Urry 2011; Cole and Ferguson 2015).

In a deeper sense, pools are also inextricably bound with processes of modernization and development brought about by the interplay between water and urbanization (Swyngedouw 2004). In Spain, for instance, the political ecological processes that have radically transformed the water environments of this country follow the classic modernization path: from the dams and reservoirs that allowed for the expansion of irrigation and hydroelectricity in the 1940s and 1950 s, to the interbasin water transfers that added water flows for urban and mass tourist growth in the Mediterranean areas of the 1960s and 1970s, and finally 
to the desalination plants that cover the new water demands, with a growing presence of outdoor uses, associated with the urbanization boom of the 1990s and 2000s (Swyngedouw 2015). It is during this last period that we must situate the expansion of swimming pools as perhaps the most recent beacon of urban modernity in the country. The collapse of the real estate market from 2008 onward and the recurring return of a difficult nature in the form of droughts and other climatic hazards, however, have combined to check water-based urban growth and threaten therefore the very fabric of urban modernity. As in Australia, California, or Florida, where swimming pools are also a fundamental part of suburban landscapes, Mediterranean Spain must face the risks and uncertainties of water-dependent urbanization models. This is why there is a need to better explore the characteristics of swimming pools and their role in urban water consumption.

Although there is already considerable research on water consumption by lawns and gardens (see, e.g., Syme et al. 2004; Yabiku, Casagrande, and FarleyMetzger 2008), we know relatively little of swimming pools due probably to the paucity of available data as well as to methodological constraints. The lack of statistical data about pools in the world and in particular in Spain justifies the exploratory nature of this research. There are some studies on this topic, for example, in Arizona or California (Beard 2007; Gross and Lee 2013) and, concerning Spain, in Barcelona (Vidal, Domene, and Saurí 2011) and the Balearic Islands and Andalusia (Hof and Wolf 2014).

In Europe, France holds the largest number of private pools (1.6 million in 2011, half of them in the southern part of the country), followed by Spain with more than 1 million pools in 2011. Spain also hosts some 62,000 estate and community pools (Market Add 2011). The penetration rate of swimming pools in Spain, defined as the number of swimming pools against the total number of single-family houses, is 4.6 percent. This figure, however, increases considerably in the Mediterranean areas, which represent 14.5 percent of swimming pools in the country (Market Add 2011). Pool development in Mediterranean Spain is intimately related with the spread of urbanization linked to residential tourism, which constituted the heart of the Spanish real estate bubble of the 1990s and 2000s (Burriel 2008).

Despite the dramatic increase in the number of swimming pools in recent decades around the world, little is known about their characteristics, especially those more directly related to water consumption. It is generally assumed that pools require large quantities of water and pools have been used, for instance, in the arguments opposing water transfers to cities threatened by droughts (March and Saurí 2013). Also, other assumptions such as that pools are luxury items only affordable by the rich need closer scrutiny given the large variety of models now present in the market. Previously seen as an indicator of a certain social status (or a "positional good" in Hirsch's
[1976] parlance), prices for swimming pools have declined considerably. For example, a medium-sized pool $\left(20-40 \mathrm{~m}^{2}\right)$ can now cost some $\$ 17,000$ on average (not including terracing and landscaping) or less than a midrange car (Morote and Hernández 2014). The particular histories of the urbanization process might modify sizes and other pool characteristics and subsequently modify also the consumption of water. This is why we need comparative studies that situate pools and pool water consumption within the more general framework of urban expansion (including residential tourism), and we especially need studies that assess pool water consumption in regard to other outdoor urban uses and other uses of water in general (Hof and Wolf 2014).

In this research we present data on swimming pools and their water consumption for the case of Alicante, Spain. Alicante is one of the fastest growing regions of southern Europe in terms of residential tourism and also one area subject to periodic water crises due to the combination of recurrent droughts and expanding agricultural, urban, and tourist water demand (Gil and Rico 2007). Our basic objective is to relate pools and their water consumption to the different typologies of residential tourism and to estimate the overall impact of swimming pools on water consumption. The article is organized as follows. After this Introduction, we highlight the main characteristics of Alicante, which shares many similarities with other Mediterranean areas regarding climate, water resources, and tourism as the main economic activity. This is followed by a methodological section in which we lay out our procedures for calculating numbers, locations, sizes, and water consumption of pools in Alicante. Then we discuss our results in the context of other studies on pools and, finally, we attempt to insist on the relevance of this topic not only for water planning and management but also for land use planning in general and, more generally, for the continuous exploration of tensions and contradictions appearing in the unfolding of water and urbanization processes.

\section{Study Area}

The province of Alicante is located in southeastern Mediterranean Spain (see Figure 1). Until the 1990s, this area enjoyed a relatively diversified product base, including irrigated agriculture, the manufacturing of consumer goods, and tourism on the coast with emblematic centers of mass tourism such as Benidorm (Rico, Olcina, and Saurí 2009). Since the late 1990s, however, a real estate bubble fueled by cheap credit absorbed a larger and larger share of the economic activity. Between 1997 and 2008, Alicante ranked third in Spain in housing units built $(345,410)$, behind Madrid and Barcelona but ahead of provinces with larger populations such as Valencia or Málaga (Hernández, Morales, and Saurí 2014). Most of this 


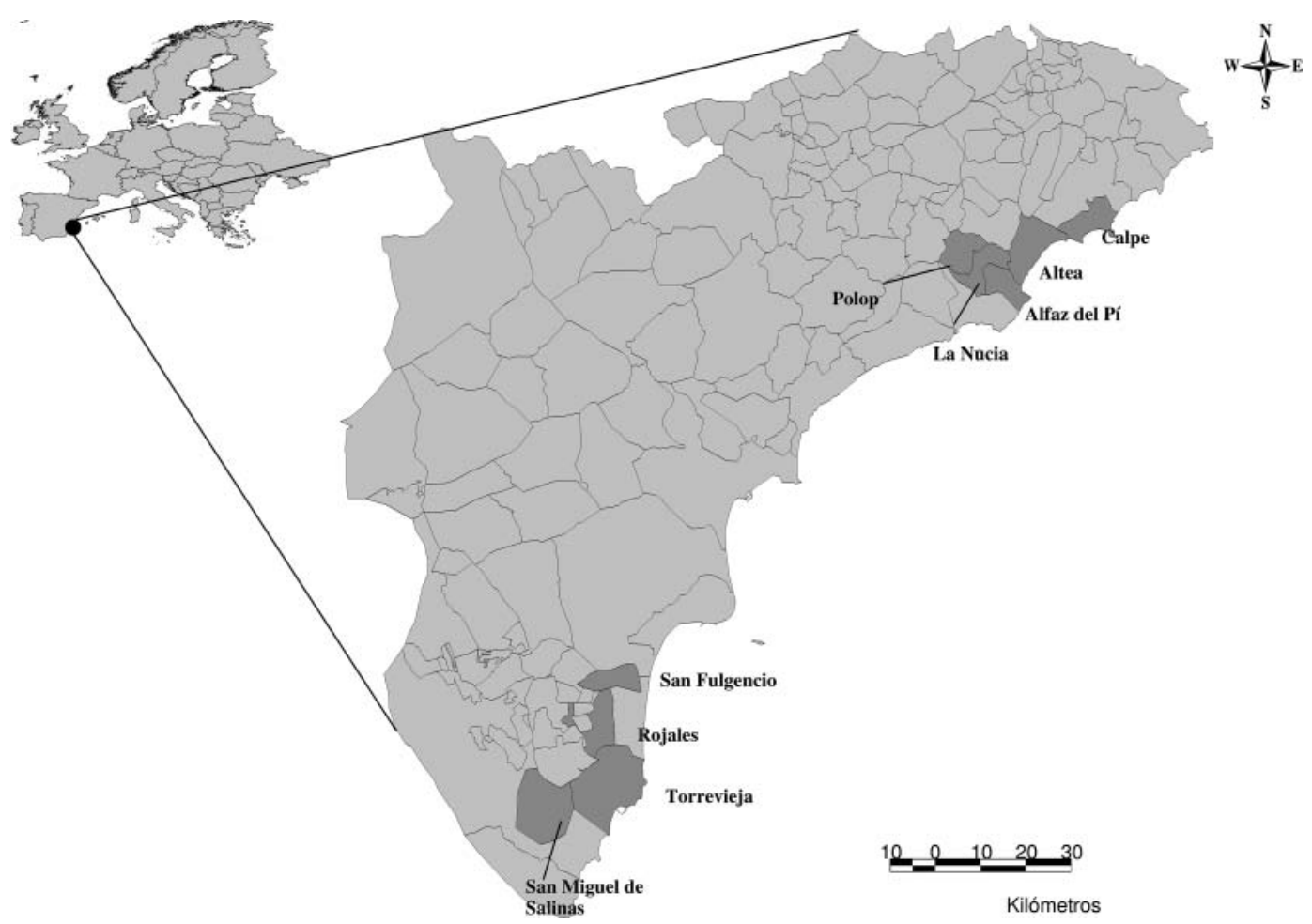

Figure 1 Study area: Province of Alicante.

urban development did not occur along the coast (already developed) but in the immediate hinterlands and aimed at international markets. In 2011, the population in Alicante was 1,852,166 inhabitants, with an increasing presence of European foreign retirees. British nationals, by far the largest foreign community, grew from some 32,500 persons in 2001 to more than 130,000 in 2011, and Norwegians rose from 3,900 to more than 10,000 in the same period. All in all, in 2011 the number of European foreigners in Alicante exceeded 330,000, 17 percent of the total population (Instituto Nacional de Estadística 2012).

To study in more detail the relationships between pools and urbanization in Alicante, nine coastal municipalities, representative of dominant residential models in this area, were selected: five municipalities of the north coast (Calpe, Altea, Polop, La Nucia, and Alfaz del Pi) and four of the south coast (San Fulgencio, Rojales, Torrevieja, and San Miguel de Salinas; see Figure 1). Differences between these two areas are related to economic income, housing characteristics, history of urban residential uses, and the intensity of the urbanization process.

The real estate bubble and the massive arrival of European foreigners also modified the urban configuration of Alicante because most growth took place on cheap land in the less developed south of the province whereas the older (in terms of urbanization) and richer north expanded more moderately. Average disposable income per person in the province of Alicante in 2009 was $14,500 €$ per year, municipalities on the north coast reached values of around $16,000 €$ per year, and those in the south barely reached $13,000 €$ per year (Rovira 2011). The real estate bubble also created a growing polarization between north and south regarding housing typologies. Single houses on often large lots were and continued to be dominant in the north, whereas in the south, smaller houses and condominiums were more common (Morote and Hernández 2016).

Regarding swimming pools, two main types of private pools were targeted in this study: pools associated with single-family homes in low-density residential developments and community or shared pools characteristic of condominiums (terraced and semidetached houses) and apartment blocks. This distinction can be traced to differences between the north and south coasts of Alicante regarding dominant urban models. Thus, urban residential uses on the north coast, beginning in the 1960s and 1970s, have followed a low-density pattern, whereas in the south, and especially during the last real estate bubble of the 2000s, the dominant model became that of the more concentrated condominium and apartment blocks (Morote 2014).

\section{Objectives, Materials, and Methods}

The objective of this research is to assess the most relevant characteristics of swimming pools on the coast of Alicante in southern Spain to estimate their water consumption and therefore elucidate the impact of these urban amenities on water demand. A better 
understanding of these features would help to improve our knowledge about the impacts of urbanization in areas where water-dependent residential sprawl has become widespread.

Annual water consumption per swimming pool area has been suggested as an indicator for monitoring the water demand of tourism (Eurostat 2009; Gössling et al. 2012). As said before, despite its relevance, quantifying pool water consumption has received little attention, mainly due to data and methodological difficulties (Hof and Wolf 2014). Pool water consumption can be estimated, however, using proxies like pool volume (Vidal, Domene, and Saurí 2011). In our case, the first step was to map the total surface area $\left(\mathrm{m}^{2}\right)$ of all swimming pools in the study area, differentiating by typology (single-family and community pool). The first type is related to detached houses and the second to residential developments of semidetached houses (condominiums) and apartment blocks. For this we used a geographical information system (GvSIG 1.12). The mapping process used orthophotographs of the Air National Orthography Plan (ANOP) of the Spanish National Geographical Institute (ING) for the year 2014. To this end, we established a web map server (www.idee.es/wms/PNOA/PNOA) connection, using the geodetic reference system ETRS 89 Zone 30 N (EPSG: 25830).

The second step was to calculate the average volume of water in pools, which required an estimation of average depths. Data on depths were collected by means of ten interviews with managers of companies engaged in the sale and installation of swimming pools in Alicante, who provided information on the average size of their best-selling pools. After these interviews we estimated the average depth of pools at $1.5 \mathrm{~m}$. This figure is similar to the one used in a study in the metropolitan area of Barcelona (Vidal, Domene, and Saurí 2011) where the average depth was $1.4 \mathrm{~m}$ and also similar to other studies in France, where average depths stand between 1.2 and $1.6 \mathrm{~m}$ (Cartier and Svetchine 2006).

We also assumed that most swimming pools had a square or rectangular form, which can be corroborated from aerial photos. Consumption could involve the total replacement of water in the pool and also partial replacements to compensate for evaporation losses, seasonal use, or the maintenance of filtration circuits. It is difficult to estimate for all pools whether owners empty and fill the pool every year or whether they cover the pool in winter. Hence, in our study, the estimation of pool water consumption is conservative, because it does not take into account water losses from filtering, leakage, overflows, emptying, or water withdrawal by pool users.

One of the most difficult aspects in the estimation of water consumption in swimming pools is losses from evaporation. In this respect, the mapped swimming pool surface area can be used to calculate water losses from evaporation and to derive estimates of pool water evaporated. To calculate these losses, we followed the method proposed by Hof and Wolf (2014) in their study of swimming pools in the Balearic Islands and Andalusia in Spain enjoying similar climatic conditions to Alicante. These authors estimated pool water consumption taking into account losses from evaporation obtained with the Penman formula, which is a semiempirical equation that combines mass transfer and energy budget methods for calculating the potential evaporation of open water using synoptic meteorological data (Penman 1948). We used evaporation data provided from the ING (2015), which is available at a regional scale. According to this source, evaporation in Alicante is estimated at $1,200 \mathrm{~mm} / \mathrm{m}^{2} /$ year. From this figure we derived average losses of pool water as 44 percent of the total volume. In the study of Vidal, Domene, and Saurí (2011) in the metropolitan area of Barcelona, average losses were estimated at 34 percent, which is consistent with the larger rainfall and lower evaporation of Barcelona compared to Alicante. After these calculations we were therefore able to obtain annual average volumes of water used per type of pool (singlefamily and community) and total water consumption.

The calculation of the number of residents and homes requires further clarification. This calculation was not based on official statistics, because these record the entire population and all housing units of any municipality, whereas this study was solely concerned with residents and homes with access to a swimming pool. For our calculations, the number of homes was the number of dwellings with a swimming pool. Moreover, we applied a ratio of 2.27 residents per home following the results of the study of Morote and Hernández (2014) for the coast of Alicante. The estimated number of housing units with access to pools, extrapolated from the average number of homes by residential development, was one home per singlefamily pool and sixty-one homes per community pool in residential developments (condominiums and apartment blocks). Finally, we obtained data about water supplied by the company managing most municipalities of the coast of Alicante (Hidraqua, Gestión Integral de Aguas de Levante S.A.).

\section{Results}

The total number of pools identified was 22,407 , of which 20,753 (92.62 percent) corresponded to pools in single-family houses and the remaining 1,654 (7.38 percent) to community pools in residential developments (Table 1). With 16.41 percent of the total, Torrevieja, on the south coast, was the only municipality where the percentage of community pools doubled the average value of this category due to the abundance of apartments and condominiums in this area since the 1960s (Vera 1987).

Regarding the number of swimming pools in each municipality, values ranged between 4,281 pools in Calpe and 350 in Polop. This extreme disparity was 
Table 1 Number and surface occupied by pools

\begin{tabular}{lcccccc}
\hline & No. total & \% single-family & \% community pools & Size $\mathbf{( m}^{\mathbf{2}} \mathbf{~}$ & \% size of single-family & \% size of community \\
\hline North coast & 12,099 & 94.60 & 5.70 & 565,393 & 85.10 & 14.90 \\
Alfaz del Pi & 2,709 & 93.47 & 6.53 & 123,333 & 81.91 & 18.09 \\
Altea & 2,376 & 93.86 & 6.14 & 132,325 & 83.30 & 16.70 \\
Calpe & 4,281 & 94.74 & 5.26 & 197,881 & 85.39 & 14.61 \\
La Nucia & 2,383 & 96.60 & 3.40 & 94,164 & 90.77 & 9.23 \\
Polop & 350 & 93.14 & 6.86 & 17,690 & 84.14 & 15.86 \\
South coast & 10,308 & 90.28 & 9.72 & 454,455 & 75.40 & 24.60 \\
Rojales & 3,603 & 93.28 & 6.72 & 146,467 & 83.98 & 16.02 \\
San Fulgencio & 1,590 & 96.67 & 3.33 & 53,114 & 89.91 & 10.09 \\
S. M. de Salinas & 1,160 & 95.09 & 4.91 & 40,050 & 88.78 & 11.22 \\
Torrevieja & 3,955 & 85.59 & 16.41 & 214,824 & 63.47 & 36.53 \\
Total & 22,407 & 92.62 & 7.38 & $1,019,839$ & 80.72 & 19.28 \\
\hline
\end{tabular}

Source: Research conducted by the authors.

related to the history and intensity of the urbanization process according to which coastal towns such as Calpe, with decades of tourist-induced development, observed much higher numbers than towns such as Polop, about ten miles from the coast and a good example of a third wave of tourist-related residential expansion into the hinterlands in the late 1990s (Navalón 1995).

The third characteristic analyzed was swimming pool size according to typology. On average, in the study area, single-family pools measured $39.67 \mathrm{~m}^{2}$, whereas community pools measured $112.73 \mathrm{~m}^{2}$. Comparisons with other countries yield interesting results. For example, in France the size of single-family pools ranged between $24 \mathrm{~m}^{2}$ and $54 \mathrm{~m}^{2}$ (Le Ravi 2013), whereas in the study of Los Angeles by Gross and Lee (2013) the average size of single-family pools was $50.55 \mathrm{~m}^{2}$. The higher figure in the U.S. study is probably due to larger land lots than those in Europe. In other areas, Hof and Wolf (2014) calculated an average size of pools of $37.8 \mathrm{~m}^{2}$ in Nova Santa Rosa (Andalusia) and $33.1 \mathrm{~m}^{2}$ in San Roque (Balearic Islands). In Alicante, the number of homes per pool was 5.42. On the north coast, results ranged between 5.11 homes per pool in Polop to 3.04 in La Nucia. On the south coast, the data were very similar, with the exception of Torrevieja, where we found 10.85 homes per pool (Figure 2), the highest number in the study area, indicating the relevance of community pools in this town.

The estimated annual water demand for a singlefamily pool was $105.33 \mathrm{~m}^{3} /$ year (Table 2) and $304.37 \mathrm{~m}^{3}$ for a community pool. These average figures mask significant differences between the north and south coasts attributable to the smaller size of the single-family pools and to the greater number of community pools in the south. The total estimated volume of water consumed by pools in the study area was $2,753,561 \mathrm{~m}^{3}$, of which 80.72 percent $\left(2,222,737 \mathrm{~m}^{3}\right)$ was consumed by single-family pools and the rest $\left(530,824 \mathrm{~m}^{3}\right)$, or 19.28 percent, by community pools. Data at the municipal level confirmed the relationship between urban typology and consumption (Figure 3). On the north coast, consumption was highest in Calpe $\left(534,279 \mathrm{~m}^{3} /\right.$ year), and 85.39 percent of this consumption was in single-family pools. In contrast, consumption was lowest in Polop, with an estimated demand of $47,763 \mathrm{~m}^{3}, 84.14$ percent of which was concentrated in single-family pools. On the south coast, the highest volume associated with community pools (36.53 percent) was observed in Torrevieja, with $580,000 \mathrm{~m}^{3} /$ year (almost a quarter of the volume of a)

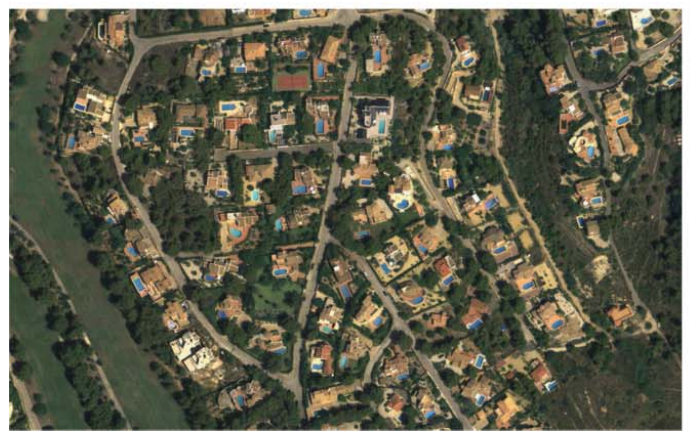

b)

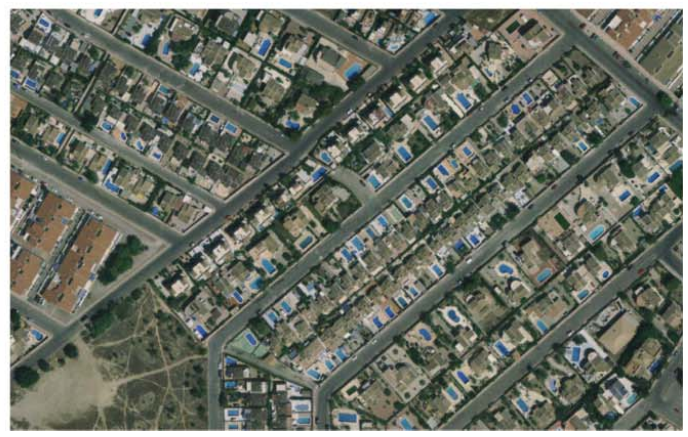

Figure 2 Images of the pools and plots $(A)$ on the north coast (Calpe) and (B) on the south coast (Torrevieja). Source: Google Maps, Image 2015 Digital Globe. (Color figure available online.) 
Table 2 Water consumption in the pool (single-family/community) per house (year/day)

\begin{tabular}{|c|c|c|c|c|}
\hline & \multicolumn{2}{|c|}{ Water consumption in the single-family pool per house } & \multicolumn{2}{|c|}{ Water consumption in the community pool per house } \\
\hline & $\mathrm{m}^{3} /$ year & Liters/day & $\mathrm{m}^{3} /$ year & Liters/day \\
\hline North coast & 115.40 & 316.14 & 5.57 & 15.28 \\
\hline Alfaz del Pi & 107.70 & 295.07 & 5.58 & 13.02 \\
\hline Altea & 133.46 & 365.63 & 6.70 & 18.35 \\
\hline Calpe & 112.38 & 307.78 & 5.69 & 15.59 \\
\hline La Nucia & 100.22 & 274.58 & 4.75 & 13.02 \\
\hline Polop & 123.26 & 337.68 & 5.17 & 14.17 \\
\hline South coast & 95.26 & 260.99 & 4.40 & 12.05 \\
\hline Rojales & 98.79 & 270.66 & 4.29 & 11.76 \\
\hline San Fulgencio & 83.29 & 229.83 & 4.48 & 12.26 \\
\hline S. M. de Salinas & 87.02 & 238.41 & 3.49 & 9.56 \\
\hline Torrevieja & 111.35 & 305.06 & 5.35 & 14.66 \\
\hline Total & 105.33 & 288.56 & 4.98 & 13.66 \\
\hline
\end{tabular}

Source: Research conducted by the authors.

water of all the study area), corroborating the importance of typologies with shared outdoor amenities.

Of relevance from the point of view of planning was the percentage that this consumption represented in the total volume of water supplied. This figure was around 10 percent in low-density typologies (singlefamily pools) and 6 percent in typologies in which community pools predominated (Morote 2014).

The fourth aspect calculated was pool water consumption by home (according to typology) and by resident. For single houses with a pool, consumption was 288.56 liters per day (Table 3). Given that the average daily consumption of these houses when permanently occupied has been estimated at 1,257 liters per home per day (Rico 2007), this implies that 22.91 percent of the total water consumed was captured by the pool. Community swimming pools consumed a significantly lower volume of water per capita (13.66 liters/day). Average daily consumption of these homes was 456 liters (Rico 2007), of which 2.99 percent was for the pool; that is a figure six to seven times smaller than in the case of individual pools. The differences between these average values became even more striking when we focus on coastal municipalities. On the north coast, water consumption of a single-family pool varied between 365.63 liters per day in Altea and 274.58 liters per day in La Nucia thanks to different average sizes for the pools $\left(49.43 \mathrm{~m}^{2}\right.$ in Altea and $37.12 \mathrm{~m}^{2}$ in La Nucia). On the south coast, these values ranged between 305.06 liters per day in Torrevieja and 229.83 liters per day in San Fulgencio. The smaller size of pools in the south was responsible for lower consumptions, and this was a characteristic also found in the community pools. In Torrevieja, for example, the average size of single-family pools was $41.24 \mathrm{~m}^{2}$, whereas in San Fulgencio it decreased to $31.07 \mathrm{~m}^{2}$.

Finally, in the case of single houses, we estimated that on average each resident consumed 127.12 liters per day of pool water, whereas in the case of community pools in condominiums or apartment blocks, on average, each resident consumed a volume of 6.04 litres per day of pool water (Table 3).

\section{Discussion: Toward a Reconsideration of Pools in the Enclaves of Residential Tourism}

Swimming pools represent outdoor urban amenities traditionally associated with wealthier segments of the population but that have extended recently to wider consumer groups as affordable, water-related items.

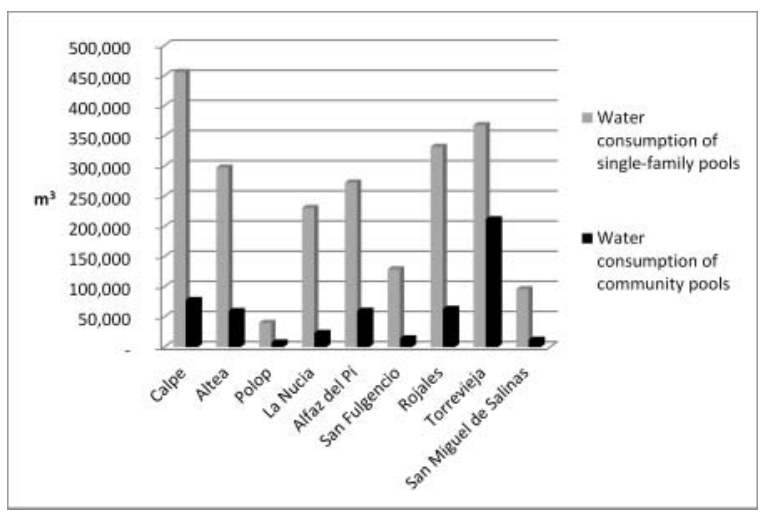

Figure 3 Water consumption in the single-family and community pools ( $\mathrm{m}^{3} /$ year). 
Table 3 Water consumption in the pool (single-family/community) per resident (year/day)

Water consumption in the single-family pool per resident Water consumption in the community pool per resident

\begin{tabular}{lcccc} 
& $\mathbf{m}^{\mathbf{3} / \mathbf{y e a r}}$ & Liters/day & $\mathbf{m}^{\mathbf{3} / \mathbf{y e a r}}$ & Liters/day \\
\cline { 2 - 5 } North coast & 50.83 & 139.27 & 2.45 & 6.77 \\
Alfaz del Pi & 47.45 & 129.99 & 2.46 & 6.73 \\
Altea & 58.79 & 161.07 & 2.95 & 8.08 \\
Calpe & 49.50 & 135.59 & 2.51 & 6.87 \\
La Nucia & 44.15 & 120.96 & 2.09 & 5.73 \\
Polop & 54.30 & 148.76 & 2.28 & 6.24 \\
South coast & 32.49 & 114.97 & 1.93 & 5.31 \\
Rojales & 43.52 & 119.23 & 1.89 & 5.18 \\
San Fulgencio & 36.96 & 101.25 & 1.97 & 5.40 \\
S. M. de Salinas & 38.34 & 105.03 & 1.54 & 4.21 \\
Torrevieja & 49.05 & 134.39 & 2.36 & 6.46 \\
Total & 41.66 & 127.12 & 2.19 & 6.04 \\
\hline
\end{tabular}

Source: Research conducted by the authors.

The lack of official statistical data about these amenities in national or local databases justifies the interest of this research that could improve knowledge of the characteristics of pools in Mediterranean Europe. In fact, laws that regulate planning and management uses have lent scant consideration to the relationship with these new uses and the implications that these new uses would have on the demands for water. In many cases, actions have been directed more to ensure an increase in resources which are in regular demand. In case of drought, actions taken consist of the prohibition of certain practices that have a strong impact on water demand, such as watering gardens and filling swimming pools (see AghaKouchak et al. [2015] for the case of the current drought in California).

In our study area, pool expansion closely follows the spread of urban land uses linked to residential tourism occurring since the 1960s (Vera 1987). A total of 22,407 pools were identified in the nine municipalities, equivalent to $1,019,833 \mathrm{~m}^{2}$, or 1 percent of the total urban area. Pool expansion and characteristics are related to the adoption of two basic urban typologies: single-family homes on the one hand and condominiums and apartment blocks on the other. In turn, these housing typologies are associated with individual and community pools, respectively. The first of these typologies predominates on the north coast, accounting for 92.62 percent of all swimming pools in the area, whereas on the southern coast of the province, and especially in the town of Torrevieja, community pools represent 16.41 percent of all pools. A longer history of residential development, larger land plots, and generally high incomes of mixed Spanish and foreign residential tourists contribute to explain the greatest presence of individual and quite large swimming pools in the north (Navalón 1995). In the south, the more recent history of urbanization, smaller land plots, a more varied housing typology, and a sizable majority of foreign residential tourists (especially retired British nationals) results in more heterogeneity regarding pools, which individually might be smaller but collectively record higher numbers and capacities.
Besides having a notable impact on the landscape, the proliferation of outdoor residential amenities such as pools could feed tensions over access to water, given the semiarid nature of this region and the weight of other sectors using water. The estimated total volume of water used for swimming pools in the study area was $2,753,561 \mathrm{~m}^{3}$. If we compare these theoretical consumptions with the water supplied, we can observe the relevance of pools. For example, in Alfaz del Pi, in 2013 water supplied by the company Hidraqua was $1,860,164 \mathrm{~m}^{3}$, of which we estimated that $332,999 \mathrm{~m}^{3}$ was consumed by pools (17.84 percent). In Rojales, in the same year, $1,475,256 \mathrm{~m}^{3}$ was supplied, of which we estimated that $395.461 \mathrm{~m}^{3}$ went to pools $(26.80$ percent). In Torrevieja, 7,734,919 $\mathrm{m}^{3}$ of water was distributed, of which $580,000 \mathrm{~m}^{3}$ was captured by pools (7.49 percent).

Although this might appear a modest quantity, it is significant to force managers to undertake conservation practices. Thus, during periods of drought, municipalities might adopt measures prohibiting the filling of swimming pools, as occurred in Altea and Murla (province of Alicante) during the summer of 2014 (Diario Información 2014). Likewise, the same municipalities are enforcing initiatives aimed at reducing consumption such as the prohibition of refilling pools every year. This is even more important given the overwhelming predominance of single-family pools that account for 80.72 percent of the total volume of water consumed.

Pools continue to expand in the more mature markets and also gain terrain in emerging markets. Many of these areas (e.g., the Middle East and North Africa or parts of Asia and Australasia) share with Alicante common socioenvironmental traits, such as arid or semiarid conditions and fast urban and tourist growth. Regarding water consumption, research in Phoenix, Arizona, for instance, shows that pools are indeed a major contributor to household water consumption (Wentz and Gober 2007) and, as in Alicante, plot size is an important variable in explaining the presence of pools. See Hof and Wolf (2014) for the Balearic Islands and Andalusia. According to previous studies 
(Vidal, Domene, and Saurí 2011), however, the amount of water consumed by pools is relatively modest when compared with water used for irrigating gardens, especially when water-demanding species are present. In this sense, a high number of pools might not imply necessarily exorbitant consumption, at least in comparison with these other outdoor uses (Domene and Saurí 2006; Parés, March, and Saurí 2013).

\section{Conclusions}

This study has attempted to explore the relationships among residential tourism, urban growth, and water consumption using the example of swimming pools in the province of Alicante, Spain. Swimming pools constitute an important outdoor water use in many areas of the world with potentially important impacts on urban water consumption, especially in arid or semiarid areas, and therefore a fundamental component of water-dependent urbanization processes subject to both social and natural tensions and constraints. Pools and lawns can often be found together in the expanding suburbs of cities following a low density pattern, as in, for example, the western and southern United States or Australia and, more recently, southern Europe. In other cases, low-density urbanism and accompanying outdoor water uses might be attributed to other factors, such as the expansion of so-called residential tourism.

Swimming pools represent a very heterogeneous reality that precludes their simple treatment as luxury items affordable by just a minority of the population. As such, they can be seen as an epitome of new but uneven urbanization and suburbanization processes that expand but also contract (as in the real estate burst of the late 2000s in Spain), leaving behind deeply transformed landscapes. As we have shown for the case of Alicante, swimming pools follow particular histories of urbanization and, large or small, their number has increased enormously in the last decades. When we relate pools to specific housing typologies, however, significant contrasts are revealed, showing again the multiple forms and associated impacts of urbanization. Thus, single houses enjoying an individual swimming pool, as in the north of the province of Alicante, capture substantial amounts of water, which on a per capita basis decrease drastically in the case of the community pools of the residential developments more common in the south. It could well be that pools are no longer a luxury item but, as the case of Alicante indicates, when we investigate the heterogeneous world of pools, important differences still appear to make this leisure artefact a good example of inequities in the access to water. Thus, the role of pools in the domestic water consumption matrix merits attention not only for water conservation efforts but also and more fundamentally for constituting yet another example of the highly uneven nature of the urbanization process both in social and environmental terms (Swyngedouw 2004).
As recommendations for urban planning strive for relatively compact forms with shared facilities (including leisure areas), recommendations for the planning of residential tourism should also search for models in which shared facilities such as swimming pools occupy a more prominent role. In this sense, our case study in Alicante could be compared with similar pool histories and geographies of areas such as Australia and California in the search for more sustainable and more socially fair modes of urbanization.

\section{Acknowledgments}

The authors would like to thank the editor and the referees for their very helpful comments and criticisms on previous versions of the article. The authors are also thankful for the data provided for the companies Hidraqua, Gestión Integral de Aguas de Levante S.A., and Aguas de Alicante, E.M.

\section{Funding}

The results presented in this article are part of two research studies. The first, entitled "Urbanisation and water metabolism in the coast of Alicante: Analysis of trends for the 2000-2010 period," was funded by the Spanish MINECO under grant number CSO201236997-C02-02. The second is part of a $\mathrm{PhD}$ research grant funded by the Spanish Ministry of Education.

\section{Literature Cited}

AghaKouchak, A., D. Feldman, M. Hoerling, T. Huxman, and J. Lund. 2015. Water and climate: Recognize anthropogenic drought. Nature 524:409-11.

Askew, L. E., and P. M. McGuirk. 2004. Watering the suburbs: Distinction, conformity and the suburban garden. Australian Geographer 35:17-37.

Balling, J. R. C., P. Gober, and N. Jones. 2008. Sensitivity of residential water consumption to variations in climate: An intraurban analysis of Phoenix, Arizona. Water Resources Research 44 (10): W10401. doi: 10.1029/2007WR006722.

Beard, B. 2007. Backyard retreats suck water, energy. http:// www.azcentral.com/news/green/articles/0716green pools0716.html (last accessed 23 February 2015).

Burriel, E. 2008. La década prodigiosa del urbanismo español (1997-2006) [Spanish prodigious decade of urbanism]. Scripta Nova 12:270. http://www.ub.es/geocrit/sn/sn-270/ sn-270-64.htm

Cartier, P., and L. Svetchine. 2006. La France des piscines [Pool's France]. Christian Ledoux.

Casado, M. 2012. The geographies of lifestyle mobilities: Exploring international retirement migration to Spain. Paper presented at the Association of American Geographers annual meeting, New York.

Catalán, B., D. Saurí, and P. Serra. 2008. Urban sprawl in the Mediterranean? Patterns of growth and change in the Barcelona Mediterranean region (1993-2000). Landscape and Urban Planning 85 (3-4): 74-84.

Cole, S. 2014. Tourism and water: From stakeholders to right holders, and what tourism business need to do. Fournal of Sustainable Tourism 22 (1): 98-106. 
Cole, S., and L. Ferguson. 2015. Towards a gendered political economy of water and tourism. Tourism Geographies 17 (4): 511-28.

Couch, C., G. Petschel-held, and L. Leontidou. 2007. Urban sprawl in Europe: Landscapes, land-use change and policy. London: Wiley-Blackwell.

Diario Información. 2014. Murla prohíbe por la sequía llenar piscinas y regar con agua potable [Murla ban full the pools and watering with drinking water due to the drought]. Diario Información 22 May 2014\. http://www.diarioin formacion.com/marina-alta/2014/05/22/murla-prohibesequia-llenar-piscinas/1504886.html (last accessed 10 January 2015).

Domene, E., and D. Saurí. 2006. Urbanization and water consumption: Influential factors in the metropolitan region of Barcelona. Urban Studies 43:1605-23.

European Environment Agency. 2006. Urban sprawl. The ignored challenge Copenhagen, Denmark: European Environment Agency. http://www.eea.europa.eu/publica tions/eea_report_2006_10 (last accessed 1 May 2014).

Eurostat. 2009. MEDSTAT II: "Water and Tourism" pilot study. Methodologies and working papers. Luxembourg: Eurostat.

Fernández, R., J. Ordovás, and M. A. Herrera. 2011. Domestic gardens as water-wise landscapes: A case study in southwestern Europe. HorTechnology 21 (5): 616-23.

Fernández, S., and D. A. Barrado. 2011. El desarrollo turístico-inmobiliario de la España mediterránea e insular frente a sus referentes internacionales (Florida y la Costa Azul): Un análisis comparado [The tourist-real estate development in the Mediterranean and insular Spain meet its international benchmarks (Florida and Costa Azul): A comparative analysis]. Cuadernos de Turismo 27:373-402.

Gil, A., and A. M. Rico. 2007. El problema del agua en la Comunidad Valenciana [The problem of water in the Valencian Community]. Valencia, Spain: Fundación de la Comunidad Valenciana Agua y Progreso.

Gössling, S. 2015. New performance indicators for water management in tourism. Tourism Management 46:233-44.

Gössling, S., P. Peeters, C. M. Hall, J. P. Ceron, G. Dubois, L. V. Lehmann, and D. Scott. 2012. Tourism and water use: Supply, demand, and security. An international review. Tourism Management 33 (1): 1-15.

Gross, B., and J. K. Lee. 2013. The big atlas of LA pools. http:// swimminginla.com/post/69306211891/the-big-atlas-of-lapools (last accessed 5 April 2015).

Hernández, M., A. Morales, and D. Saurí. 2014. Ornamental plants and the production of natures in the Spanish real estate boom and burst: The case of Alicante. Urban Geography 35 (1): 71-85.

Hirsch, F. 1976. Social limits to growth. Cambridge, MA: Harvard University Press.

Hof, A., and M. Blázquez. 2013. The linkages between real estate tourism and urban sprawl in Majorca (Balearic Islands, Spain). Land Use Policy 2:252-77.

Hof, A., and N. Wolf. 2014. Estimating potential outdoor water consumption in private urban landscapes by coupling high-resolution image analysis, irrigation water needs and evaporation estimation in Spain. Landscape and Urban Planning 123:61-72.

Huete, R., A. Mantecón, and T. Mazón. 2008. ¿De qué hablamos cuando hablamos de turismo residencial [What do we mean when we talk about residential tourism?] Cuadernos de Turismo 22:101-21.

Instituto Nacional de Estadística. 2012. Censos de población y vivienda. 1991, 2001 y 2011 [Census of population and housing]. http://www.ine.es/inebmenu/mnu_cifraspob. htm (last accessed 20 April 2015).

Leichenko, R. M., and W. D. Solecki. 2005. Exporting the American dream: The globalization of suburban consumption landscapes. Regional Studies 39:241-53.

Le Ravi. 2013. 12 euros pour remplir sa piscine [12 euros for full the pool] http://archive.wikiwix.com/cache/? url=http://www.leravi.org/spip.php?article1476\&ti tle $=\% \mathrm{C} 2 \% \mathrm{AB} \% \mathrm{C} 2 \% \mathrm{~A} 012 \% 20$ euros\%20pour\%20rempli r\%20sa\%20piscine\%C2\%A0\%C2\%BB (last accessed 15 February 2015).

March, H., and D. Saurí. 2013. La sequera del 2007-2008 a la ciutat de Barcelona: Gènesi, gestió i visions discordants [The drought of 2007-2008 in the city of Barcelona: Start, management and discordant views]. Treballs de la Societat Catalana de Geografia 76:289-306.

Market Add. 2011. El sector de la piscina en España: Síntesis de resultados [The business of the pool in Spain]. Federación de Asociaciones de Fabricantes de equipos y construcciones de piscinas salinas y spas. http://www. salonpiscina.com

McWatters, M. 2009. Residential tourism: (De)constructing paradise. Bristol, UK: Channel View.

Morote, A. F. 2014. Tipologías urbano-residenciales del litoral de Alicante: Repercusiones territoriales [Urban and residential typologies in the coast of Alicante: Land aftermaths]. Ciudad y Territorio: Estudios Territoriales 46 (181): 431-43.

Morote, A. F., and M. Hernández. 2014. Jardines y urbanizaciones, nuevas naturalezas urbanas en el litoral de la provincia de Alicante [Gardens and housing developments, new urban natures on the coast of the province of Alicante]. Documents d'Anàlisi Geogràfica 60 (3): 483-504.

-2016. Urban sprawl and its effects on water demand: A case study of Alicante, Spain. Land Use Policy 50:352-62.

Navalón, R. 1995. Planeamiento urbano y turismo residencial en los municipios litorales de Alicante [Urban planning and residential tourism in the coastal villages of Alicante]. Alicante: Instituto de Cultura Juan Gil-Albert.

Parés, M., H. March, and D. Saurí. 2013. Atlantic gardens in Mediterranean climates: Understanding the production of suburban natures in Barcelona. International fournal of Urban and Regional Research 37 (1): 328-47.

Penman, H. L. 1948. Natural evaporation from open water, bare soil and grass. Proceedings of the Royal Society A: Mathematical, Physical and Engineering Sciences 193 (1032): $120-45$.

Raya, P., and J. J. Benítez. 2002. Concepto y estimación del turismo residencial: Aplicación en Andalucía [Meaning and estimation of the residential tourism: Application in Andalusia]. Papers de Turisme 31-32:67-89.

Rico, A. M. 2007. Tipologías de consumo de agua en abastecimientos urbano-turísticos de la Comunidad Valenciana [Water consumption typologies in urban and tourist supply systems in the Valencian Community]. Investigaciones Geográficas 42:5-34.

Rico, A. M., J. Olcina, and D. Saurí. 2009. Tourist land use patterns and water demand: Evidence from the western Mediterranean. Land Use Policy 26:493-501.

Robbins, P. 2012. Lawn people: How grasses, weeds, and chemicals make us who we are. Philadelphia: Temple University Press.

Rovira, A. 2011. Atlas socio-económico de la Comunidad Valenciana [Social and economic atlas of the Valencian 
Community]. Valencia, Spain: Generalitat Valenciana y Consejo de Cámaras Oficiales de Comercio, Industria y Navegación de la Comunidad Valenciana.

Salvà, P. 2002. Foreign immigration and tourism development in Spain's Balearic Islands: Tourism and migration. New relationships between production and consumption. London: Kluwer.

Salvador, R., C. Bautista-Capetillo, and E. Playán. 2011. Irrigation performance in private urban landscapes: A study case in Zaragoza (Spain). Landscape and Urban Planning 100 (3): 302-11.

Salvati, L., E. Ridolfi, I. Zambon, P. Serra, and D. Saurí. 2015. Swimming pools as indicator of urban sprawl: An exploratory analysis in a Mediterranean city. International Fournal of Environmental Research 9 (4): 1325-32.

Salvati, L., and A. Sabbi. 2011. Exploring long term land cover changes in an urban region of southern Europe. International Fournal of Sustainable Development and World Ecology 18 (4): 273-82.

Spanish National Geographic Institute (ING). 2015. Evaporación media anual [Annual average evaporation]. http://www.ign.es/espmap/mapas_clima_bach/Mapa_clima_ 08.htm (last accessed 20 March 2015).

Staddon, C. 2010. Managing Europe's water resources: 21st century challenges. Farnham, UK: Ashgate.

Swyngedouw, E. 1999. Modernity and hybridity: Nature, regenerationism and the production of the Spanish waterscape, 1890-1930. Annals of the Association of American Geographers 89 (3): 443-65.

. 2004. Social power and the urbanization of water. Oxford, UK: Oxford University Press.

- 2014. "Not a drop of water ...": State, modernity and the production of nature in Spain, 1898-2010. Environment and History 20:67-92.

- 2015. Liquid power: Contested hydro-modernities in twentieth century Spain. Cambridge, MA: MIT Press.

Syme, G. J., Q. Shao, M. Po, and E. Campbell. 2004. Predicting and understanding home garden water use. Landscape and Urban Planning 68:121-28.

Urry, J. 2011. Climate change and society. Cambridge, UK: Polity.

Van Leeuwen, T. 1999. The springboard in the pond: An intimate history of the swimming pool. Cambridge, MA: MIT Press.
Vera, J. F. 1987. Turismo y urbanización en el litoral alicantino [Tourism and urbanization in the coast of Alicante]. Alicante, Spain: Instituto de Estudios Juan Gil-Albert.

Vidal, M., E. Domene, and D. Saurí. 2011. Changing geographies of water-related consumption: Residential swimming pools in suburban Barcelona. Area 43 (1): 67-75.

Wentz, E., and P. Gober. 2007. Determinants of small-area water consumption in Phoenix, Arizona. Water Resources Management 21:1849-1963.

Wiltse, J. 2007. Contested waters: A social history of swimming pools in America. Chapel Hill: University of North Carolina Press.

Wolf, N., and A. Hof. 2013. Integration of the pixel and object domain for the mapping of new urban landscapes in the Mediterranean with a focus on outdoor water consumption. EARSeL eProceedings 12 (1): 67-81.

Yabiku, S. T., D. G. Casagrande, and E. Farley-Metzger. 2008. Preferences for landscape choice in a Southwestern desert city. Environment and Behavior 40:382-400.

ÁLVARO-FRANCISCO MOROTE is a researcher in the Interuniversity Institute of Geography at University of Alicante, Carretera de Sant Vicent del Raspeig, Alicante, 03080 Spain. E-mail: alvaro.morote@ua.es. His research interests include studies about water consumption, the urbanization process, and natural hazards.

DAVID SAURÍ is Full Professor of Geography at the Universitat Autònoma de Barcelona, Department of Geography, Autonomous University of Barcelona, 08193 Bellaterra, Cerdanyola del Vallès, Spain. E-mail: david.sauri@uab.cat. His research has focused on environmental hazards, water resources management (particularly in urban and tourist environments), and nature-society theories. He has authored or coauthored more than seventy papers in international journals. He is a member of the Academia Europea.

MARÍA HERNÁNDEZ is Full Professor of Geography in the Interuniversity Institute of Geography at University of Alicante, Alicante, 03080 Spain. E-mail: maria.hernandez@ua.es. Her research interests, initiated in 1994, are focused on studies on analysis and evolution of rural and cultural landscapes, agriculture and rural development, tourism and local development, land management, demand and water uses, and natural hazards. 